\title{
Klasifikasi K-NN dalam Identifikasi Penyakit COVID-19 Menggunakan Ekstraksi Fitur GLCM
}

\author{
Nisa Nafisah ${ }^{1 *}$, Riza Ibnu Adam ${ }^{2 *}$, Carudin ${ }^{3 *}$ \\ * Teknik Informatika, Universitas Singaperbangsa Karawang \\ nisa.nafisah17162@student.unsika.ac.id ${ }^{1}$, riza.adam@staff.unsika.ac.id ${ }^{2}$, carudin@staff.unsika.ac.id $^{3}$
}

\begin{tabular}{l} 
Article Info \\
\hline Article history: \\
Received 2021-08-12 \\
Revised 2021-10-20 \\
Accepted 2021-10-22 \\
\hline
\end{tabular}

Keyword:

Covid-19,

GLCM,

Data mining,

$K-N N$

\begin{abstract}
Covid-19 merupakan penyakit yang sedang mewabah di berbagai belahan dunia termasuk Indonesia. Penyakit ini menginfeksi saluran pernapasan yang disebabkan oleh jenis virus corona baru. Untuk mengetahui adanya virus covid-19 di dalam tubuh dapat dilakukan pemeriksaan medis seperti cek darah, pemeriksaan radiologi rontgent (x-ray) dan swab. Penelitian ini melakukan identifikasi penyakit covid-19 berdasarkan citra rongen yang mana citra tersebut diekstraksi menggunakan metode fitur ekstraksi GLCM yaitu contrast, correlation, energy, dan homogeneity. Setelah didapat nilai dari ekstraksi lalu diklasifikasikan menggunakan metode klasifikasi data mining yaitu k-nearest neighbor dengan melakukan 3 pemodelan nilai inputan $k$. Hasil penelitian yang diperoleh dari pengklasifikasian didapat akurasi sebesar $80 \%$ pada model 3 dengan nilai $\mathrm{k}=5$ dan pada model 1 dan 2 diperoleh hasil akurasi sebesar $90 \%$ dengan nilai $k=1$ dan $k=3$.
\end{abstract}

\section{Pendahuluan}

Pandemi yang sedang melanda seluruh dunia belakangan ini merupakan penyakit Coronavirus Disease 2019 atau COVID-19 yang mana penyakit ini menginfeksi saluran pernafasan yang disebabkan oleh jenis virus corona baru. Virus corona merupakan sekelompok besar virus yang memiliki duri seperti mahkota di permukaannya, dalam kata latin untuk mahkota berarti coronam [1]. Sebelumnya, pada tahun 2002 telah terjadi pandemic yang disebabkan oleh virus corona yang menginfeksi saluran pernapasan yang bernama SARS-CoV (Severe Acture Respiratory Syndrome) [2] dan juga pada tahun 2012 terjadi infeksi virus MERS-CoV yang pertama kali teridentifikasi di Saudi Arabia [3]. Sehingga organisasi Kesehatan dunia atau WHO menetapkan SARSCoV-2 sebagai virus yang menyebabkan penyakit COVID19. Untuk mengetahui adanya COVID-19 di dalam tubuh, diperlukan pemeriksaan medis seperti rapid test, swab, dan PCR. Orang yang memiliki gejala-gejala terindikasi COVID19 akan di pinta melakukan cek darah, pemeriksaan radiologi rontgent menggunakan sinar-x (X-ray), lalu dilanjutkan swab [4]. Gejala-gejala orang terindikasi penyakit COVID-19 meliputi demam atau menggigil, batuk, sesak napas, sulit bernapas, kelelahan, pegal-pegal, sakit kepala, hilangnya indra perasa atau penciuman, sakit tenggorokan, hidung tersumbat atau meler, mual atau muntah, dan diare [5]. Pemeriksaan radiologi berperan penting dalam melawan COVID-19 yaitu dapat menilai dan melihat perkembangan kondisi penyakit pada pasien karena pada beberapa kasus menyatakan negative pada tes virologi sedangkan saat dilakukan pemeriksaan radiologi dapat menunjukan adanya infeksi virus pada tahap awal [6]. Radiologi itu sendiri merupakan cabang ilmu kedokteran yang bertujuan untuk mengetahui bagian dalam tubuh manusia menggunakan teknologi pencitraan yang berperan untuk diagnos penyakit, salah satu kondisinya yaitu untuk mengetahui adanya kelainan pada paru-paru [7]. Salah satu pemeriksaan radiologi yaitu pemeriksaan foto rontgent. Rontgent merupakan tes diagnostic berbasis pencitraan dengan sinar-x (x-ray) yang bertujuan untuk melihat bagian dalam tubuh sepeti paru-paru dan saluran pernapasan dalam bentuk citra [8]. Oleh karena permasalahan tersebut, maka pada penelitian akan dilakukan pengidentifikasian penyakit COVID-19 berdasarkan citra Xray.

Beberapa penelitian yang telah mengimplementasikan pengetahuan teknik pada citra medis yakni Afriyana, Purnamasari, \& Patmasari [9] yang mendeteksi kelainan tulang belakang dengan menggunakan gray level co- 
occurrence matrix (GLCM) dan k-nearest neighbor (KNN) dimana dalam proses pengujiannya dilakukan dengan menggunakan 128 citra tulang belakang, dengan kelas citra normal 53 citra, 36 citra dekstroskoliosis, dan 39 citra levoskoliosis. Hasil yang diperoleh dengan akurasi sebesar $84,84 \%$ pada sistem dengan parameter GLCM orde dua di keempat parameter, dengan arah $0^{\circ}, 45^{\circ}, 90^{\circ}, 135^{\circ}$ dan level kuantitas 8, sedangkan pada parameter $\mathrm{KNN}$ dengan nilai $\mathrm{k}=$ 1 di keempat parameter yang digunakan.

Selanjutnya [10] penelitian yang telah dilakukan mendeteksi penyakit COVID-19 berdasarkan citra X-Ray yang menggunakan pendekatan deep learning berbasis residual dep network dengan melakukan evaluasi untuk mengetahui performa metode berupa precision, recall, F1, dan accuracy. Hasil yang diperoleh dengan menggunakan metode ini memberikan nilai precision 0.98 , recall 0.95 , F1 0.97, dan accuracy sebesar $99 \%$.

Penelitian selanjutnya [11] mengklasifikasikan pneumonia menggunakan metode K-Nearest Neighbor (K-NN) dan ekstraksi fitur gray level co-occurrence matrix (GLCM). Terdapat beberapa tahapan sebelum dilakukan pengklasifikasian yaitu cropping, resizing, contrast stretching, dan thresholding. Hasil yang diperoleh dari penelitian ini menunjukan bahwa akurasi terbaik per kelas adalah $66,20 \%$ untuk $\mathrm{k}=5$.

Lalu pada penelitian ini akan dilakukan pengklasifikasian penyakit COVID-19 dengan mengimplementasikan teknik data mining, data mining merupakan penguraian pengetahuan yang terdapat pada basis data untuk memperoleh informasi yang pada prosesnya menggunakan teknik statistik, matematika, kecerdasan buatan, dan machine learning [12], salah satu teknik data mining yang akan digunakan yaitu metode $k$-nearest nighbor (K-NN) yang mana parameter untuk pengklasifikasian diperoleh dari nilai-nilai fitur ekstraksi metode gray level co-occurrence matrix (GLCM) yakni contrast, correlation, energy, dan homogeneity agar dapat mengidentifikasi penyakit COVID-19 berdasarkan citra radiologi x-ray thorax. Thorax itu sendiri merupakan bagian tubuh yang terletak di antara leher dan abdomen[13] yang berbentuk.kerucut yaitu lebih besar pada bagian bawah daripada bagian atasnya dan lebih panjang pada bagian belakang daripada depan, yang tersusun atas rangka tulang dada (Sternum), 12 ruas tulang belakang (Thoracalis), dan 12 pasang tulang rusuk [14]

\section{Metode Penelitian}

\section{A. Data Preparation}

Tahap awal pada penelitian ini dilakukan persiapan data, dataset yang digunakan diperoleh dari situs terbuka Kaggle.com, pada dataset terdapat 69 citra terinfeksi COVID19 dan 25 citra normal dengan total 94 citra dengan format .JPG, lalu citra yang telah disiapkan akan diklasifikasikan berdasarkan hasil ekstraksi fitur GLCM dengan 4 fitur nilai yang akan menjadi parameter yakni contrast, correlation, energy, dan homogeneity.

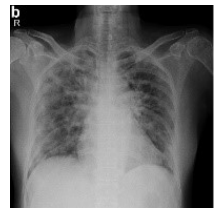

(i)

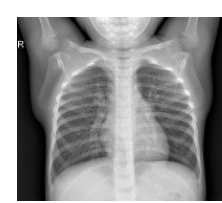

(ii)
Gambar 1. (i) Citra yang terindikasi COVID-19 dan (ii) Citra yang tidak terindikasi COVID-19

\section{B. Preprocessing}

Sebelum dilakukan proses pengklaasifikasian data mining, dilakukan preprocessing pada data citra yang akan digunakan.

- Konversi citra RGB ke grayscale

Setelah data citra diperoleh, tahap awal preprocessing yaitu memastikan data citra yang akan digunakan sudah dalam skala keabuan. Pada data terdapat beberapa citra yang masih berskala warna $R G B$. Untuk merubah citra $R G B$ menjadi grayscale, metode umum yang digunakan yaitu dapat dilihat pada persamaan 1 .

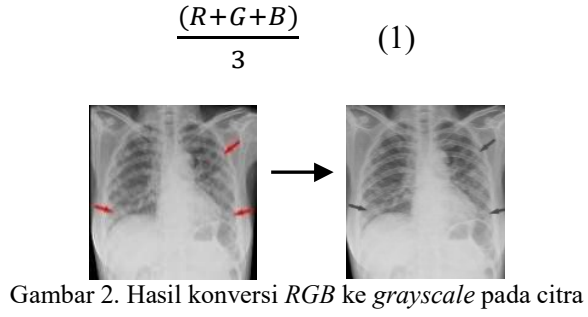

\section{- $\quad$ Cropping Citra}

Setelah semua data citra sudah dalam skala keabuan, langkah selanjutnya yaitu dilakukannya pemangkasan atau cropping pada citra, karena data citra yang diperoleh memiliki beragam pengambilan sudut gambar, maka dilakukan cropping untuk menyamakan tiap citra agar tepat pada objek yang akan diklasifikasikan yaitu paru-paru.

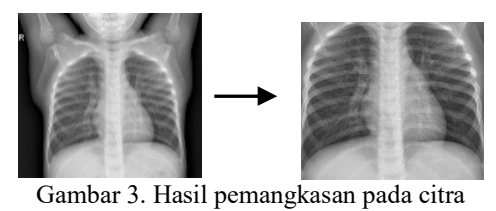

- Resize Citra

Setelah pemangkasan citra dilakukan, selanjutnya dilakukan resize pada citra karena ukuran tiap data citra yang telah di pangkas berbeda-beda, maka agar mempermudah proses ekstraksi fitur, dilakukan normalisai pada ukuran tiap data citra sebesar 250x250 piksel. 


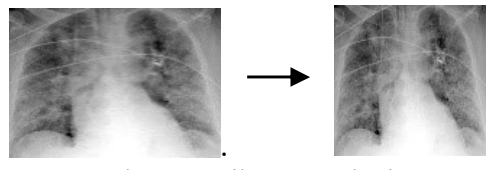

Gambar 4. Hasil resize pada citra

\section{Ekstraksi Fitur}

Setelah dilakukan penyamaan ukuran pada tiap data citra, lalu selanjutnya dilakukan ekstraksi fitur GLCM ekstraksi fitru merupakan proses pengenalan ciri juga menganalisis tekstur dalam suattu objek, tekstur tersebut dibuktikn dengan persamaan matematika, sehingga pada proses pengenalan dapat dibandingkan dengan objek lainnya menggunakan hasiil analisis tekstur tersebut [15].

Metode yang digunakan dalam ekstraksi fitur yaitu GLCM, GLCM merupakan salah satu metode yang efektif yang dapat melakukan klasifikasi dan identifikasi dengna memproses ekstraksi ciri [11] dimana GLCM itu sendri merupakan suatu matriks yang elemennya merupakan jumlah pasangan piksel yang memiliki tingkat kecerahan tertentu yang pada pikselnya tepisah oleh jarak $d$ dan suatu sudut inklinasi $\theta$ [16]. Terdapat 4 fitur yang umumnya dipakai dalam berbagai penelitian yakni contrast, correlation, energy, dan homogeneity.

1) Contrast yaitu fitur yang melakukan perhitungan pada jumlah keberagaman intensitas keabuan citra. Nilai contrasr akan semakin tinggi jika derajat keabuan setiap pasangan pikselnya semakin jauh.

$$
\text { Contrast }=\sum_{x} \sum_{y}|x-y|^{2} \cdot p(x, y)
$$

2) Correlation yaitu fitur yang melakukan perhitungan untuk menujukan ukuran ketergantungan derajat keabuan pada citra untuk memberikan petunjuk adanya struktur linear dalam citra.

$$
\text { Correlation }=\frac{\sum_{x} \sum_{y}\left(x-\mu_{x}\right) \cdot\left(y-\mu_{y}\right) \cdot p(x, y)}{\sigma_{x} \sigma_{y}}
$$

3) Energy yaitu fitur yang menyatakan konsetrasi pasangan dengan intensitas keabuan pada matriks

$$
\text { Energy }=\sum_{x} \sum_{y}\{p(x, y)\}^{2}
$$

4) Homogeneity yaitu jumlah level keabuan yang sejenis pada citra jika piksel semakin seragam maka nilai homogeneity makin tinggi.

$$
\text { Homogeneity }=\sum_{x} \sum_{y} \frac{p(x, y)}{1+|x-y|}
$$

\section{HASIL DAN EVALUASI}

\section{A. Modelling}

Setelah data citra di ekstraksi, lalu membagi dataset dilakukan pemodelan menggunakan algoritma k-nearest neighbor dan naïve bayes.

K-nearest neighbor merupakan salah satu algoritma klasifikasi sederhana yang menyimpan semua kondisi dan mengklasifikasikan ke dalam kondisi baru berdasarkan jarak terpendek [17] dimana metode ini diproses berdasarkan jarak terpendek dari query instance ke data latih lalu mengambil $\mathrm{k}$ buah data terdekat [18]. Eucliden distance salah satu perhitungan untuk menghitung jarak pada data baru dengan data lama [19] [20].

$$
d(x, y)=\sqrt{\sum_{i=1}^{n}\left(x_{i}-y_{i}\right)^{2}}
$$

Pada tahap pemodelan dilakukan dengan menggunakan 3 model, yaitu sebagai berikut.

\section{1) Model 1}

Pada model 1 dilakukan pemodelan k-nearest neighbor dengan nilai $k=1$, hasil klasifikai dapat dilihat pada table I.

TABEL I

HASIL KLASIFIKASI MODEL 1

\begin{tabular}{|l|l|}
\hline \multicolumn{1}{|c|}{ Kelas } & \multicolumn{1}{c|}{$\begin{array}{c}\text { Hasil } \\
\text { Klasifikasi }\end{array}$} \\
\hline Covid 1 & Benar \\
\hline Covid 2 & Benar \\
\hline Covid 3 & Benar \\
\hline Covid 4 & Benar \\
\hline Covid 5 & Benar \\
\hline Covid 6 & Benar \\
\hline Covid 7 & Benar \\
\hline Normal 1 & Benar \\
\hline Normal 2 & Salah \\
\hline Normal 3 & Benar \\
\hline
\end{tabular}

\section{2) Model 2}

Pada model 2 dilakukan pemodelan k-nearest neighbor dengan nilai $\mathrm{k}=3$, hasil klasifikai dapat dilihat pada table II.

TABEL II HASIL KLASIFIKASI MODEL 2

\begin{tabular}{|l|l|}
\hline \multicolumn{1}{|c|}{ Kelas } & \multicolumn{1}{c|}{$\begin{array}{c}\text { Hasil } \\
\text { Klasifikasi }\end{array}$} \\
\hline Covid 1 & Benar \\
\hline Covid 2 & Benar \\
\hline Covid 3 & Benar \\
\hline Covid 4 & Benar \\
\hline Covid 5 & Benar \\
\hline Covid 6 & Benar \\
\hline Covid 7 & Benar \\
\hline Normal 1 & Benar \\
\hline
\end{tabular}




\begin{tabular}{|l|l|}
\hline Normal 2 & Salah \\
\hline Normal 3 & Benar \\
\hline
\end{tabular}

\section{3) Model 3}

Pada model 3 dilakukan pemodelan k-nearest neighbor dengan nilai $k=5$, hasil klasifikai dapat dilihat pada table III.

TABEL III

HASIL KLASIFIKASI MODEL 3

\begin{tabular}{|l|l|}
\hline \multicolumn{1}{|c|}{ Kelas } & \multicolumn{1}{c|}{$\begin{array}{c}\text { Hasil } \\
\text { Klasifikasi }\end{array}$} \\
\hline Covid 1 & Benar \\
\hline Covid 2 & Benar \\
\hline Covid 3 & Benar \\
\hline Covid 4 & Benar \\
\hline Covid 5 & Benar \\
\hline Covid 6 & Benar \\
\hline Covid 7 & Benar \\
\hline Normal 1 & Benar \\
\hline Normal 2 & Salah \\
\hline Normal 3 & Salah \\
\hline
\end{tabular}

\section{B. Evaluation}

Setelah dilakukan pemodelan menggunakan algoritma knearest neighbor dengan nilai $k=1,3$, dan 5 diperoleh hasil akurasi dengan menggunakan persamaan berikut.

$$
\text { Akurasi }=\frac{\text { Jumlah benar }}{\text { Jumlah Data Uji }} \times 100 \%
$$

Pada model 1, pemodelan algoritma k-nearet neighbor dengan nilai $k=1$ menghasilkan 1 nilai kesalahan output yang tida sesuai dengan kelas pada data uji ke 9, maka diperoleh hasil akurasi sebesar $90 \%$ dari total 10 data uiji.

$$
\text { Akurasi }=\frac{9}{10} \times 100 \%=90 \%
$$

Pada model 2, pemodelan algoritma k-nearet neighbor dengan nilai $k=3$ juga menghasilkan 1 nilai kesalahan output yang tidak sesuai dengan kelas pada data uji ke 9, maka diperoleh hasil akurasi sebaesar $90 \%$ dari total 10 data uiji.

$$
\text { Akurasi }=\frac{9}{10} \times 100 \%=90 \%
$$

Lalu pada model 3, pemodelan algoritma k-nearet neighbor dengan nilai $k=5$ menghasilkan 2 nilai kesalahan output yang tidak sesuai dengan kelas pada data uji ke 9 dan 10, maka diperoleh hasil akurasi sebaesar $80 \%$ dari total 10 data uiji.

$$
\text { Akurasi }=\frac{8}{10} \times 100 \%=80 \%
$$

\section{Hasil}

Pada tahap ini dilakukan pengimplementasian terhadap model yang telah diperoleh dengan menggunakan model yang memiliki akurasi terbaik yaitu dengan nilai $k=3$ untuk dimasukan ke dalam program yang dibangun pada aplikasi bantu MATLAB dan menyiapkan 5 data baru untuk dilakukan pengujian. Hasil klasifikasi pada citra dapat dilihat pada gambar berikut.

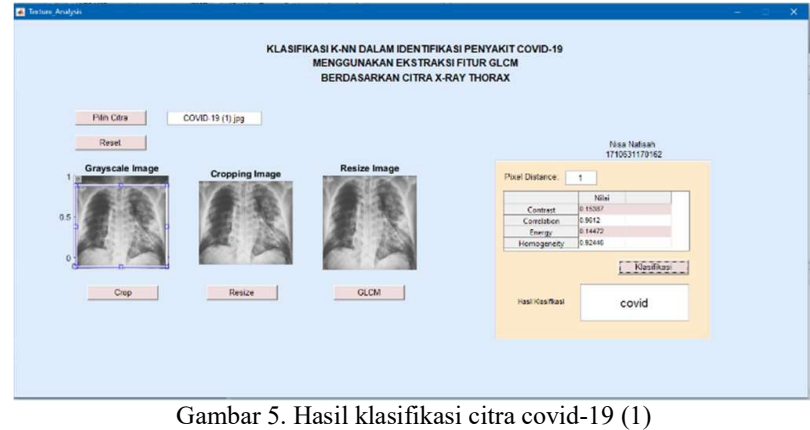

Gambar 5. Hasil klasifikasi citra covid-19 (1)

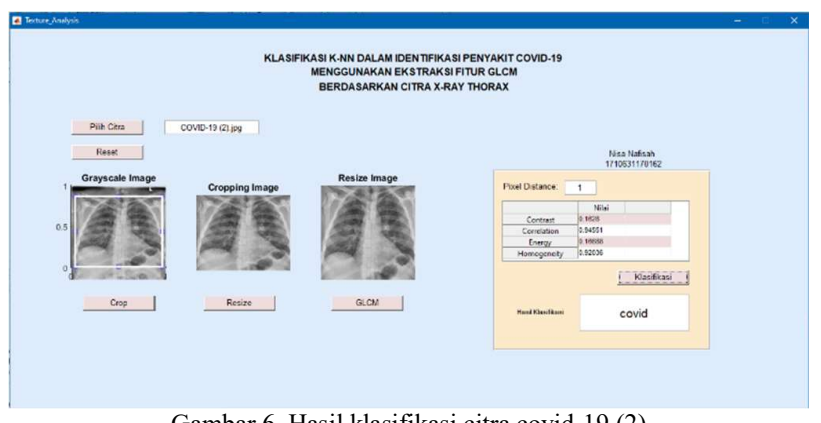

Gambar 6. Hasil klasifikasi citra covid-19 (2)

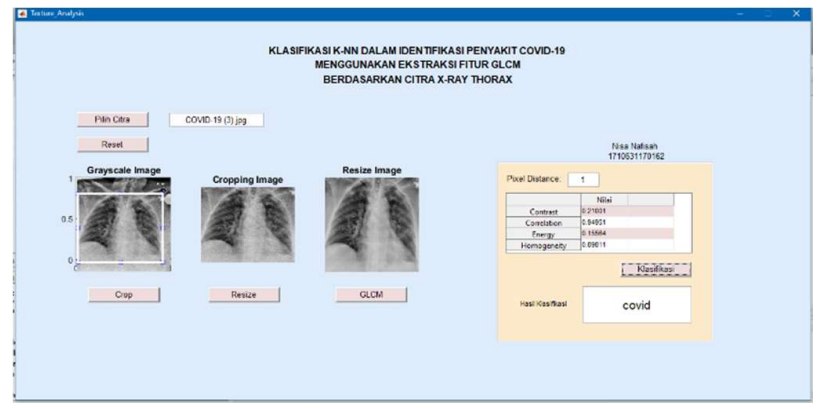

Gambar 7. Hasil klasifikasi citra covid-19 (3)

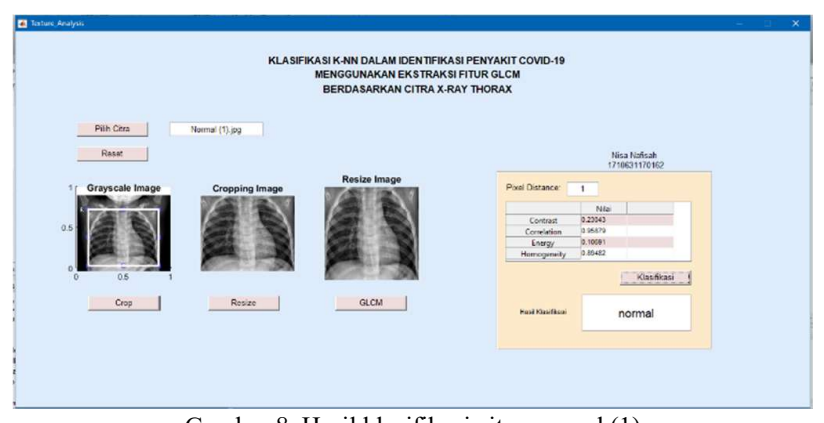

Gambar 8. Hasil klasifikasi citra normal (1) 


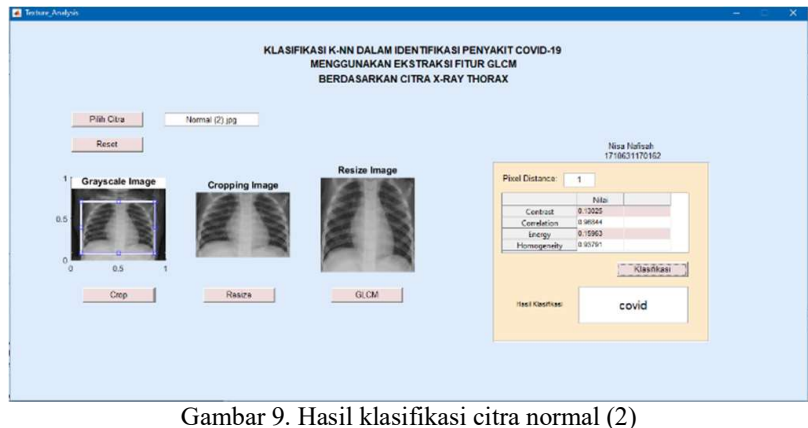

\section{KESIMPULAN}

Hasil pembahasan yang diperoleh dari penelitian yang telah dilakukan, dapat diambil beberapa kesimpulan diantaranya pengidentifikasian penyakit Covid-19 berdasarkan citra x-ray thorax dengan parameter atribut hasil dari ekstraksi fitur GLCM atau gray level co-occurrence matrix yaitu contrst, correlation, energy, dan homogeneity menggunakan Teknik klasifikasi data mining k-nearest neighbor atau k-nn dengan melakukan 3 pemodelan untuk mendapatkan hasil akurasi terbaik. Hasil yang diperoleh ddengan menggunakan Teknik klasifikasi data mining knearest neghbor memperoleh hasil akurasi terbaik pada nilai $k=1$ dan $k=3$ dengan akurasi sebesar $90 \%$.

\section{DAFTAR PUSTAKA}

[1] J. Huizen, "Why is it called coronavirus?" 2020 https://www.medicalnewstoday.com (accessed Mar. 08, 2021).

[2] M. D. C. Pane, "SARS," 2020. https://www.alodokter.com/sars.

[3] N. R. Aida, "7 Wabah Virus yang pernah Mengguncang Dunia Selain Corona," 2020 https://www.kompas.com/tren/read/2020/02/06/171200465/7-wabahvirus-yang-pernah-mengguncang-dunia-selaincorona?amp $=1$ \&page $=3 \&$ jxconn $=1$ *la 89 al $*$ other jxampid*NmhETI FUTDVGbmJDaWdIUXZ4OW9FX2U3LVIVOTRnOVhQS21QSD k4YWpHZGxoZWNDM0hiTURoVG5iNXNjS0c2Tw.

[4] Tim, "Berita Kesehatan: Kegunaan Tes Darah, Rontgen, dan Swab," 2020. https://m.cnnindonesia.com (accessed Mar. 14, 2021).

[5] Cdc.gov, "Symptoms," 2021.
[6] B. Yanti and U. Hayatun, "Peran pemeriksaan radiologi pada diagnosis Coronavirus disease 2019," J. Kedokt. Syiah Kuala, pp. 53$57,2020$.

[7] H. R, "Artikel: Perlu Tahu, Ini Jenis-Jenis Pemeriksaan Radiologi," Halodoc.com, 2019. https://www.halodoc.com (accessed Apr. 14, 2021).

[8] M. Helmi, "Rontgent," 2020. https://www.sehatq.com (accessed Apr. 14, 2021).

[9] Y. Afriyana, R. Purnamasari, and R. Patmasari, "Deteksi Kelainan Tulang Belakang Berdasarkan Citra Medis Digital Dengan Menggunakan Gray Level Co-occurence Matrix (GLCM) dan Knearest Meighbor (KNN)," in e-Proceeding of Engineering, 2018, pp. 4657-4682.

[10] Y. . Hariyani, S. Hadiyoso, and T. SupraptoSiadari, "Deteksi Penyakit COvid-19 Berdasarrkan Citra X-Ray Menggunakan Deep Residual Network," ELKOMIKA J. Tek. Energi Elektr. Tek. Inform. Tek. Elektron., pp. 443-453, 2020.

[11] C. Wijaya, H. Irsyad, and W. Widhiarso, "Klasifikasi Pneumonia Menggunakan KNearest Neighbor Dengan Ekstraksi GLCM," J. Algoritm., pp. 33-44, 2020.

[12] G. Gunadi and D. I. Sensue, "Penerapan Metode Data Mining Market Basket Analysis Terhadap Data Penjualan Produk Buku Dengan Menggunaan Algoritma Apriori Dan Freequent Pattern Growth (FpGrowth) : Studi Kasus Percetakan Pt.Gramedia," J. Telemat. MKOM, vol. 4, pp. 118-132, 2012.

[13] R. N. Hayati, "Segmentasi Paru-Paru Pada Citra Digital Hasil X-Ray Thorax Menggunakan Metode Level Set Untuk Menghitung Diameer Maksimal Paru-Paru,” 2013.

[14] N. Surani, "Berita: Mengenal Rongent Thorax (Dada)," RS Betha Medika, $2017.2 \quad$ https://www.kasihgroup.com/id/berita/3836/mengenal-rontgen-thorax-dada- (accessed Apr. 19, 2021)

[15] H. A. Pitoyo, "Implementasi Metode Support Machine Untuk Klasifikasi Daun Mangga Berdasarkan Tekstur Daun,” 2020.

[16] I. Purnamasari and T. Stujo, "Pengenalan Ciri Garis Telapak Tangan Menggunakan Ekstraksi Fitur (Glcm) Dan Metode K-Nn," J. VOI(Voice Informatics), pp. 32-41, 2017.

[17] D. S. Sayad, "datamining," 2010. https://chemeng.utoronto.ca/ datamining/.

[18] F. Agustina and Z. A. Ardiansyah, "Identifikasi Citra Daging Ayam Kampung dan Mroiler Menggunakan Metoe GLCM dan KlasifikasiNN," J. INFOKAM, 2020.

[19] D. E. Kurniawan and A. Dzikri, "Pengenalan Personal Berdasarkan Pengukuran Jarak Citra Wajah Menggunakan Pendekatan Linear dan Nonlinear," in Seminar Nasional Teknik Informatika dan Komputer, 2015, pp. 1-4.

[20] D. E. Kurniawan, "Identifikasi Citra Wajah Menggunakan Gaborbased Kernel Principal Component Analysis," in Applied Business and Engineering Conference (ABEC 2014), 2014, pp. 1-5. 